\title{
Microstructure Evolution and Hot Deformation Behavior of a CuNiSn Alloy
}

\author{
Yexin Jiang ${ }^{1,2}$, Xu Wang ${ }^{1}$, Zhou Li ${ }^{1,3}$, Zhu Xiao ${ }^{1,4, *}$, Xiaofei Sheng ${ }^{1,5}$, Hongyun Jiang ${ }^{6}$, Gengsheng Cai ${ }^{1}$ \\ and Xianwei Zhang ${ }^{2}$
}

check for

updates

Citation: Jiang, Y.; Wang, X.; Li, Z.; Xiao, Z.; Sheng, X.; Jiang, H.; Cai, G.; Zhang, X. Microstructure Evolution and Hot Deformation Behavior of a CuNiSn Alloy. Processes 2021, 9, 451. https://doi.org/10.3390/pr9030451

Academic Editor: Chi-Min Shu

Received: 21 January 2021

Accepted: 10 February 2021

Published: 2 March 2021

Publisher's Note: MDPI stays neutral with regard to jurisdictional claims in published maps and institutional affiliations.

Copyright: (c) 2021 by the authors. Licensee MDPI, Basel, Switzerland. This article is an open access article distributed under the terms and conditions of the Creative Commons Attribution (CC BY) license (https:// creativecommons.org/licenses/by/ $4.0 /)$.
1 School of Materials Science and Engineering, Central South University, Changsha 410083, China; jiangyexin2021@sohu.com (Y.J.); 183111043@csu.edu.cn (X.W.); lizhou6931@csu.edu.cn (Z.L.); 123101011@csu.edu.cn (X.S.); caigsh@gwi.gd.cn (G.C.)

2 CNMC Albetter Albronze Co., Ltd., Linqing 252600, China; xianwei2021@sina.com

3 State Key Laboratory of Powder Metallurgy, Changsha 410083, China

4 Key Laboratory of Nonferrous Metal Materials Science and Engineering, Ministry of Education, Changsha 410083, China

5 School of Engineering, Huzhou University, Huzhou 313000, China

6 Zhejiang Tianning Alloy Material Co., Ltd., Jinhua 321002, China; jianghongyun@zjtnhj.com

* Correspondence: xiaozhumse@csu.edu.cn

\begin{abstract}
The hot deformation behavior of Cu-20.0Ni-5.0Sn-0.25Zn-0.22Mn was investigated using a Gleeble-3500 thermal simulator with a temperature range from $720{ }^{\circ} \mathrm{C}$ to $880{ }^{\circ} \mathrm{C}$ and a strain rate range from $0.001 \mathrm{~s}^{-1}$ to $1 \mathrm{~s}^{-1}$. The results show that the flow stress increased with the increase of the strain rate and the decrease of the temperature. The constitutive equation of the alloy was established based on the peak flow stress. Figures of the power dissipation efficiency and flow instability with the variable of the true strain from 0.2 to 0.8 displayed the dynamic change of power dissipation efficiency and the instability area. The domain of $730-770{ }^{\circ} \mathrm{C}$ and $0.001-0.01 \mathrm{~s}^{-1}$ possessed a power dissipation efficiency over $40 \%$ throughout the whole deformation. The flow instability always appeared at a high strain rate from $0.1 \mathrm{~s}^{-1}$ to $1 \mathrm{~s}^{-1}$ during the whole deformation process. The nucleation site of the dynamic recrystallization generally appeared along the grain boundaries, indicating the discontinuous dynamic recrystallization mechanism. The appropriate conditions for deformation with a true strain of 0.9 is in a safe domain $\left(820-860{ }^{\circ} \mathrm{C}\right.$ with a strain rate of $0.001-0.01 \mathrm{~s}^{-1}$ ). There were four kinds of variation tendencies of the power dissipation efficiency with the increase of the true strain under various conditions, suggesting a changing situation for the main softening mechanisms.
\end{abstract}

Keywords: microstructure evolution; hot deformation behavior; CuNiSn alloy

\section{Introduction}

Copper alloys with ultra-high strength have been widely used in electronic and electrical engineering due to their excellent elasticity and good electrical conductivity. Copper-beryllium alloy is a commonly used elastic copper alloy. However, the beryllium vapor generated during the production process is hypertoxic, and copper-beryllium alloys have the disadvantage of poor stress relaxation resistance [1-3]. As a typical spinodal decomposition-strengthening copper alloy, the environmentally friendly Cu-Ni-Sn alloy has been increasingly applied as a substitute for the copper-beryllium alloy [4]. Cu-NiSn alloys have a good combination of mechanical properties, electrical properties, stress relaxation resistance, corrosion resistance, and wear resistance after reasonable composition design and thermomechanical treatment [5-7]. For example, the yield strength of the $\mathrm{Cu}$ $15 \mathrm{Ni}-8 \mathrm{Sn}-0.8 \mathrm{Nb}$ alloy was up to $1230 \mathrm{MPa}$ when the sample was vortically swaged by a $45 \%$ reduction and then aged at $400{ }^{\circ} \mathrm{C}$ for $0.5 \mathrm{~h}$ [8]. Luo et al. found that the addition of $0.5 \mathrm{Si}$ into $\mathrm{Cu}-9 \mathrm{Ni}-2.5 \mathrm{Sn}-1.5 \mathrm{Al}$ could increase the mechanical properties of the as-extruded 
samples, with a tensile strength of $861 \mathrm{MPa}$ and elongation of $18 \%$ [7]. Therefore, $\mathrm{Cu}-\mathrm{Ni}-\mathrm{Sn}$ alloys are frequently used as bearings, bushings, and corrosion-resistant parts in aerospace, marine, oil exploration, and transmission engineering $[9,10]$.

The segregation of $\mathrm{Sn}$ often occurs during the casting process of $\mathrm{Cu}-\mathrm{Ni}-\mathrm{Sn}$ alloys due to the big differences in the surface tensions and melting points between $\mathrm{Sn}$ and $\mathrm{Cu}$, and they have a great influence on the properties of the alloy $[4,6,11]$. The inhomogeneity of the alloy caused by the segregation could increase with the increasing content of Sn [5]. This heterogeneity may result in cracks in the ingot during the hot rolling process, which can bring difficulties to the industrial production and industrialization of $\mathrm{Cu}-\mathrm{Ni}-\mathrm{Sn}$ alloys. One way to solve this problem is to add a trace alloy element whose surface tension is between $\mathrm{Cu}$ and $\mathrm{Sn}$, such as $\mathrm{Zn}$ or Mn. Another way is to decrease the content of the Sn element. Therefore, in our work, we designed a Cu-20.0Ni-5.0Sn-0.25Zn-0.22Mn alloy. Moreover, optimizing the hot working parameters of $\mathrm{Cu}-\mathrm{Ni}-\mathrm{Sn}$ alloys, including temperature and strain rate, can effectively figure out the problem.

The constitutive equations and hot working maps, based on the dynamic materials model (DMM) established through thermal compression simulation tests, are often used to predict the hot working conditions of alloys. The deformation behavior of the alloys, including work hardening, dynamic recovery, and dynamic recrystallization, could be evaluated by the constitutive equations and hot working maps to analyze the hot deformation process. This method has been successfully used in various copper alloys. Zhang et al. found that the suitable deformation temperature was only over $800{ }^{\circ} \mathrm{C}$ for $\mathrm{Cu}-8.0 \mathrm{Ni}-1.8 \mathrm{Si}-0.15 \mathrm{Mg}$ alloys [12]. Sun et al. concluded that the addition of Ag into $\mathrm{Cu}-\mathrm{Ni}-\mathrm{Si}$ could increase the critical strain of dynamic recrystallization, and the optimal deformation condition was $700-800{ }^{\circ} \mathrm{C}$ and $0.01-0.46 \mathrm{~s}^{-1}$ for $\mathrm{Cu}-2.0 \mathrm{Ni}-0.5 \mathrm{Si}-0.15 \mathrm{Ag}$ alloys [13]. Rare elements in $\mathrm{Cu}-\mathrm{Mg}$ could refine the grains and increase the activation energy of $\mathrm{Cu}-\mathrm{Mg}$ alloys, which was verified by the work of Wang et al. [14]. Liu et al. investigated the deformation behavior of $\mathrm{Cu}-3 \mathrm{Ti}-3 \mathrm{Ni}-0.5 \mathrm{Si}$ alloys and calculated the suitable parameters of hot deformation for the alloy, those being $750-810^{\circ} \mathrm{C}$ with a strain rate of $0.1 \mathrm{~s}^{-1}$, and the instability domains of the alloys were $700-730{ }^{\circ} \mathrm{C}$ with a strain rate of $0.1-10 \mathrm{~s}^{-1}$ and $820-850{ }^{\circ} \mathrm{C}$ with a strain rate of $1-10 \mathrm{~s}^{-1}$ [15]. However, there are few relevant studies on the constitutive equations and hot working maps of Cu-Ni-Sn alloys, especially the newly designed Cu-20.0Ni-5.0Sn-0.25Zn$0.22 \mathrm{Mn}$ alloy in this article. Therefore, it is necessary to establish the hot working maps and study the evolution of the microstructure of the Cu-20.0Ni-5.0Sn- $0.25 \mathrm{Zn}-0.22 \mathrm{Mn}$ alloy with a low $\mathrm{Sn}$ content during hot deformation through thermal compression simulation testing.

In this paper, a Cu-20.0Ni-5.0Sn-0.25Zn-0.22Mn alloy was designed. The thermal deformation ability of the alloy was investigated through thermal compression simulation testing. The temperatures and strain rates used in the test were $720-880^{\circ} \mathrm{C}$ and $0.001-1 \mathrm{~s}^{-1}$, respectively. The constitutive equation, 3D power dissipation efficiency maps, and 3D instability maps of the $\mathrm{Cu}-\mathrm{Ni}-\mathrm{Sn}-\mathrm{Zn}-\mathrm{Mn}$ alloy were established. The evolution of the microstructure of the samples, which deformed at typical regions on the hot working map during the compression process, was studied through optical microscopy (OM) and transmission electron microscopy (TEM). The hot working map under a true strain of 0.9 was partitioned into an unsuitable deformation area, a safe deformation area, and an unsafe area. Furthermore, the change rules of power dissipation efficiency with the increasing true strain under different conditions were drawn out for the analysis and discussion of the relationship among the change rules, dynamic recovery, and dynamic recrystallization. The results could be expected to provide on-site guidance for the hot deformation parameters of $\mathrm{Cu}-\mathrm{Ni}-\mathrm{Sn}-\mathrm{Zn}-\mathrm{Mn}$ alloys in industrial production.

\section{Materials and Methods}

The ingot of the $\mathrm{Cu}-20.0 \mathrm{Ni}-5.0 \mathrm{Sn}-0.25 \mathrm{Zn}-0.22 \mathrm{Mn}$ alloy investigated in this work was melt in a medium-frequency induction furnace under the protection of an argon atmosphere. The raw materials were pure copper, pure nickel, pure tin, pure zinc, and pure manganese. After the defects of the surface of the ingot were removed by mechanical 
cutting, the ingot was homogenization-treated at $830{ }^{\circ} \mathrm{C} / 2 \mathrm{~h}+850{ }^{\circ} \mathrm{C} / 2 \mathrm{~h}$. Cylindrical specimens with a diameter of $8 \mathrm{~mm}$ and a height of $12 \mathrm{~mm}$ were prepared for thermal simulation test by wire electrode cutting, followed by surface smoothing treatment.

The thermal simulation test of the hot compression deformation was carried out on a Gleeble-3500 thermal simulator. The range of the temperature and strain rate for the test were $720-880^{\circ} \mathrm{C}$ and $0.001-1 \mathrm{~s}^{-1}$, respectively. Graphite flakes were placed between the specimens and the collets to reduce the impact of friction. The specimens were heated to the set test temperature at a rate of $5{ }^{\circ} \mathrm{C} / \mathrm{s}$ and held at the temperature for 3 minutes, ensuring that the specimens were evenly heated. The specimens were compressed with a nominal reduction of $60 \%$ from $12 \mathrm{~mm}$ to $4.8 \mathrm{~mm}$ and immediately quenched in water after the hot deformation was finished. The schematic diagram of the technological process of the whole experiment is shown in Figure 1.

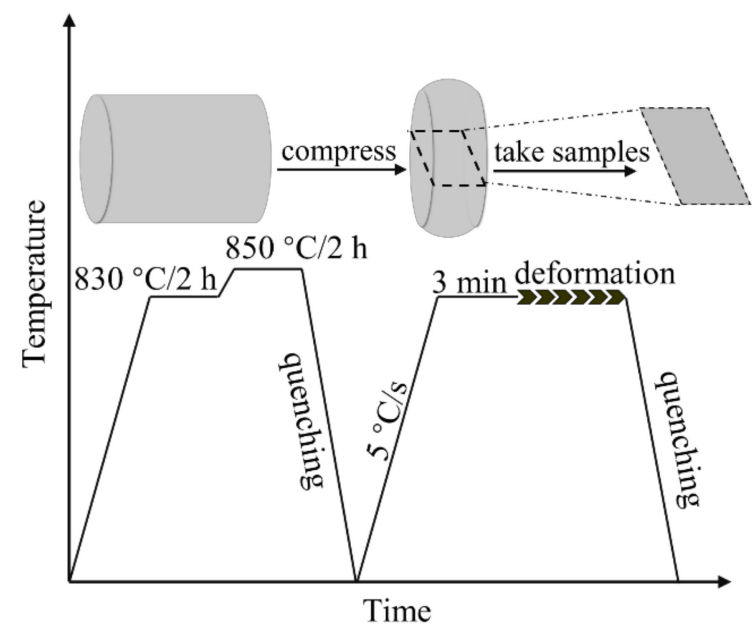

Figure 1. The schematic diagram of the technological process of the whole experiment.

The samples for microstructure observation were cut parallel with the compression direction and through the center of the deformed specimens as described in Figure 1. The optical micrograph samples were etched into a metallographic etchant consisting of $\mathrm{FeCl}_{3}(5 \mathrm{~g}), \mathrm{HCl}(25 \mathrm{~mL})$, and pure water $(75 \mathrm{~mL})$ after mechanical polishing. The transmission electron microscopy (TEM) round samples with a diameter of $3 \mathrm{~mm}$ were first thinned mechanically to about $50 \mu \mathrm{m}$ and then electropolished using a Struers Tenupol-5 electrolytic instrument with a temperature of $-35^{\circ} \mathrm{C}$. The component of the electropolishing solution was $30 \% \mathrm{HNO}_{3}$ and $70 \% \mathrm{CH}_{3} \mathrm{OH}$ in volume. The optical microscopy $(\mathrm{OM})$ images were taken on a Leica DM6000M microScheme 220 transmission electron microscope.

\section{Results}

\subsection{Flow Stress Curves}

The true stress-true strain curves of the Cu-Ni-Sn-Zn-Mn alloy when compressed in a thermal simulation test under different deformation conditions are shown in Figure 2. The deformation temperature and strain rate had a significant effect on the flow stress. The value of the flow stress increased with the increasing strain rate but decreased obviously with the the increasing deformation temperature. The flow stress value is usually concerned with the competitive relationship between work hardening caused by dislocation accumulation and softening from dynamic recovery (DRV) and dynamic recrystallization (DRX). According to Figure 2, the variation tendency of the flow stress curves could be divided into three parts: the work hardening stage, the softening stage, and the steady stage. At the work hardening stage, the flow stress increased rapidly to the peak stress. This is because the dislocation density increased as dislocation accumulated. When the stored energy during the deformation process reached the critical value, DRV and DRX occurred, and the deformation transferred into the softening stage [16]. At this stage, 
the softening effect was larger than that of work hardening, leading to a decrease in the flow stress. During the steady stage, the work hardening effect and softening effect arrived at a dynamic balance point, and the flow stress stayed at a stable status at this stage. Under several deformation conditions, such as a low temperature $\left(720^{\circ} \mathrm{C}\right)$ and a high strain rate $\left(0.1 \mathrm{~s}^{-1}\right.$ and $\left.1 \mathrm{~s}^{-1}\right)$, the steady stage was not obvious. This is because the effect of dynamic recrystallization was not strong enough, and the main softening mechanism was dynamic recovery in this condition.
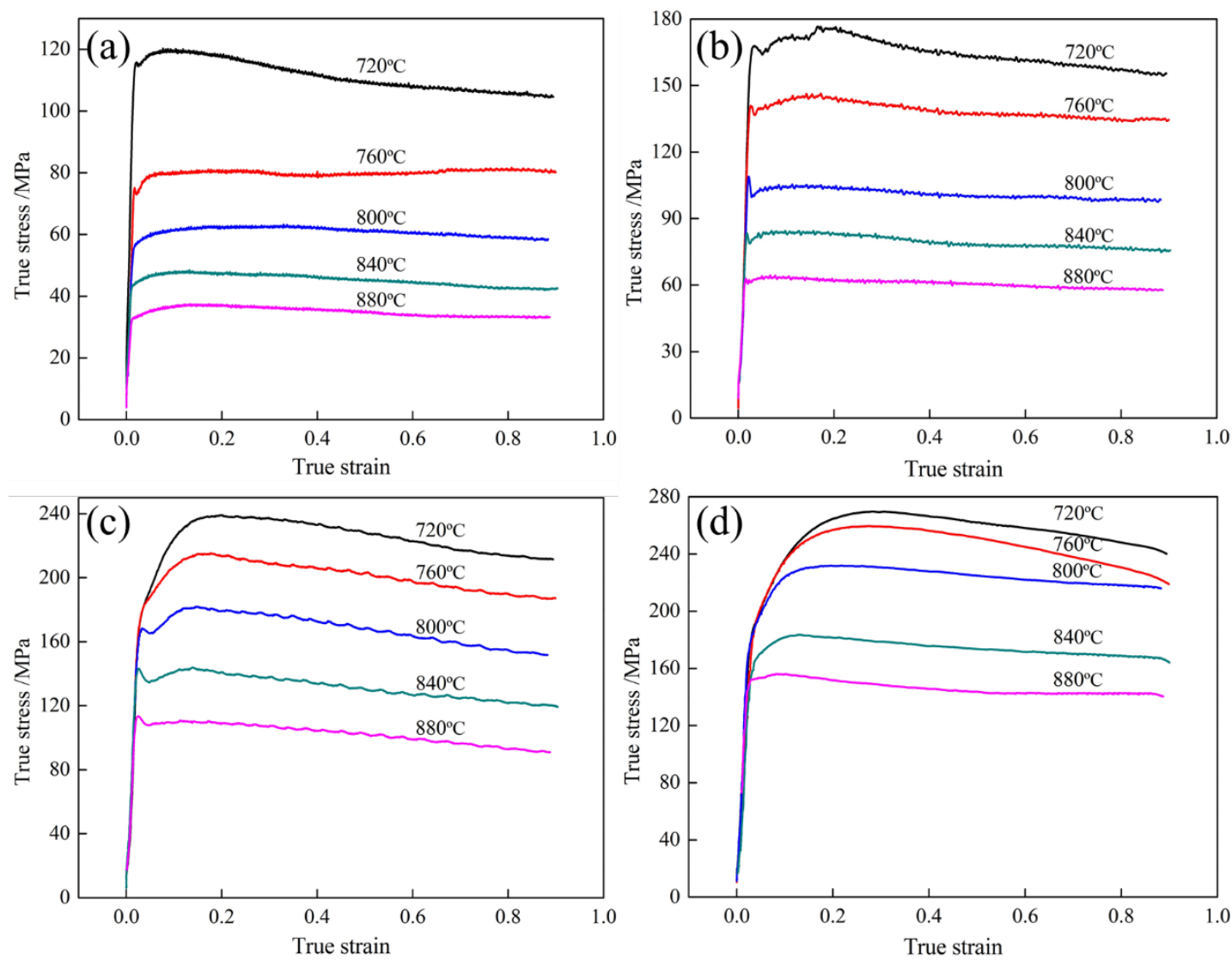

Figure 2. True stress-true strain curves of the Cu-Ni-Sn-Zn-Mn alloy at a strain rate of (a) $0.001 \mathrm{~s}^{-1}$, (b) $0.01 \mathrm{~s}^{-1}$, (c) $0.1 \mathrm{~s}^{-1}$, and (d) $1 \mathrm{~s}^{-1}$.

\subsection{Construction and Analysis of Constitutive Equations}

The relationship among the deformation temperature $(T)$, strain rate $(\dot{\varepsilon})$, and peak flow stress $(\sigma)$ can be expressed by different forms of Arrhenius-type equations [17]:

$$
\begin{gathered}
\dot{\varepsilon}=A_{1} \sigma^{n_{1}} \exp \left(-\frac{Q}{R T}\right) \\
\dot{\varepsilon}=A_{2} \exp (\beta \sigma) \exp \left(-\frac{Q}{R T}\right) \\
\dot{\varepsilon}=A_{3}[\sinh (\alpha \sigma)]^{n} \exp \left(-\frac{Q}{R T}\right)
\end{gathered}
$$


where $A_{1}, A_{2}, A_{3}, n_{1}$, and $\beta$ are materials constants, $\alpha=\beta / n_{1}, n$ is the stress exponent, $Q$ is the apparent activation energy $(\mathrm{kJ} / \mathrm{mol})$ for hot compression deformation, and $R$ $(8.314 \mathrm{~kJ} / \mathrm{mol} / \mathrm{K})$ is the gas constant. Equation (1) and Equation (2) are suitable at the low flow stress $(\alpha \sigma<0.8)$ and high flow stress states $(\alpha \sigma>0.8)$, respectively, and Equation (3) is suitable for all stress ranges. The relationship among the flow stress, deformation temperature, and strain rate is called the Zener-Hollomon parameter, according to the study of Zener and Hollomon, and it can be expressed as [18].

$$
Z=A_{3}[\sinh (\alpha \sigma)]^{n}=\dot{\varepsilon} \exp \left(\frac{Q}{R T}\right)
$$

By taking the natural logarithms of the two sides of Equations (1)-(4), the following equations can be acquired:

$$
\begin{gathered}
\ln \dot{\varepsilon}=n_{1} \ln \sigma-\frac{Q}{R T}+\ln A_{1} \\
\ln \dot{\varepsilon}=\beta \sigma-\frac{Q}{R T}+\ln A_{2} \\
\ln \dot{\varepsilon}=n \ln [\sinh (\alpha \sigma)]-\frac{Q}{R T}+\ln A_{3} \\
\ln Z=n \ln [\sinh (\alpha \sigma)]+\ln A_{3}
\end{gathered}
$$

The values of $n 1$ and $\beta$ can be obtained from the average slopes of the linear fits of $\ln \dot{\varepsilon}-\ln \sigma$ (Figure 3a) and $\ln \dot{\varepsilon}-\sigma$ (Figure 3b), respectively. $n 1$ and $\beta$ were calculated to be 5.69 and $0.05 \mathrm{MPa}^{-1}$, respectively, and thus, $\alpha$ was $0.0088 \mathrm{MPa}^{-1} . n$ is the average slopes of the linear fits of $\ln \dot{\varepsilon}$ versus $\ln [\sinh (\alpha \sigma)]$ at different temperatures, which was calculated to be 4.15, as shown in Figure 3c.

To obtain the value of $Q$, Equation (7) takes the partial derivatives of both sides and is converted into Equation (9):

$$
Q=1000 R\left\{\frac{\partial \ln \dot{\varepsilon}}{\partial \ln [\sinh (\alpha \sigma)]}\right\}_{T}\left\{\frac{\partial \ln [\sinh (\alpha \sigma)]}{\partial(1000 / T)}\right\}_{\dot{\varepsilon}}=1000 R n s
$$

where $s$ stands for the average slopes of the linear fits of $\ln [\sinh (\alpha \sigma)]$ versus $(1000 / T)$ at various strain rates, computed to be 8.55 as shown in Figure $3 \mathrm{~d}$. Therefore, $Q$ was determined to be $295.1 \mathrm{~kJ} / \mathrm{mol}$. The peak flow stress under all deformation conditions was used to calculate the values of $\ln Z$, according to Equation (4). The value of $\ln A_{3}$, which was 29.3, was obtained by calculating the intercept of the linear fits of $\ln Z$ versus $\ln [\sinh (\alpha \sigma)]$ on the basis of Equation (8) in Figure 3e.

On the grounds of the analysis and results shown above, the constitutive equation of $\mathrm{Cu}-\mathrm{Ni}-\mathrm{Sn}-\mathrm{Zn}-\mathrm{Mn}$ can be expressed as:

$$
\dot{\varepsilon}=[\sinh (0.0088 \sigma)]^{4.15} \exp \left[29.3-\frac{295100}{R T}\right]
$$



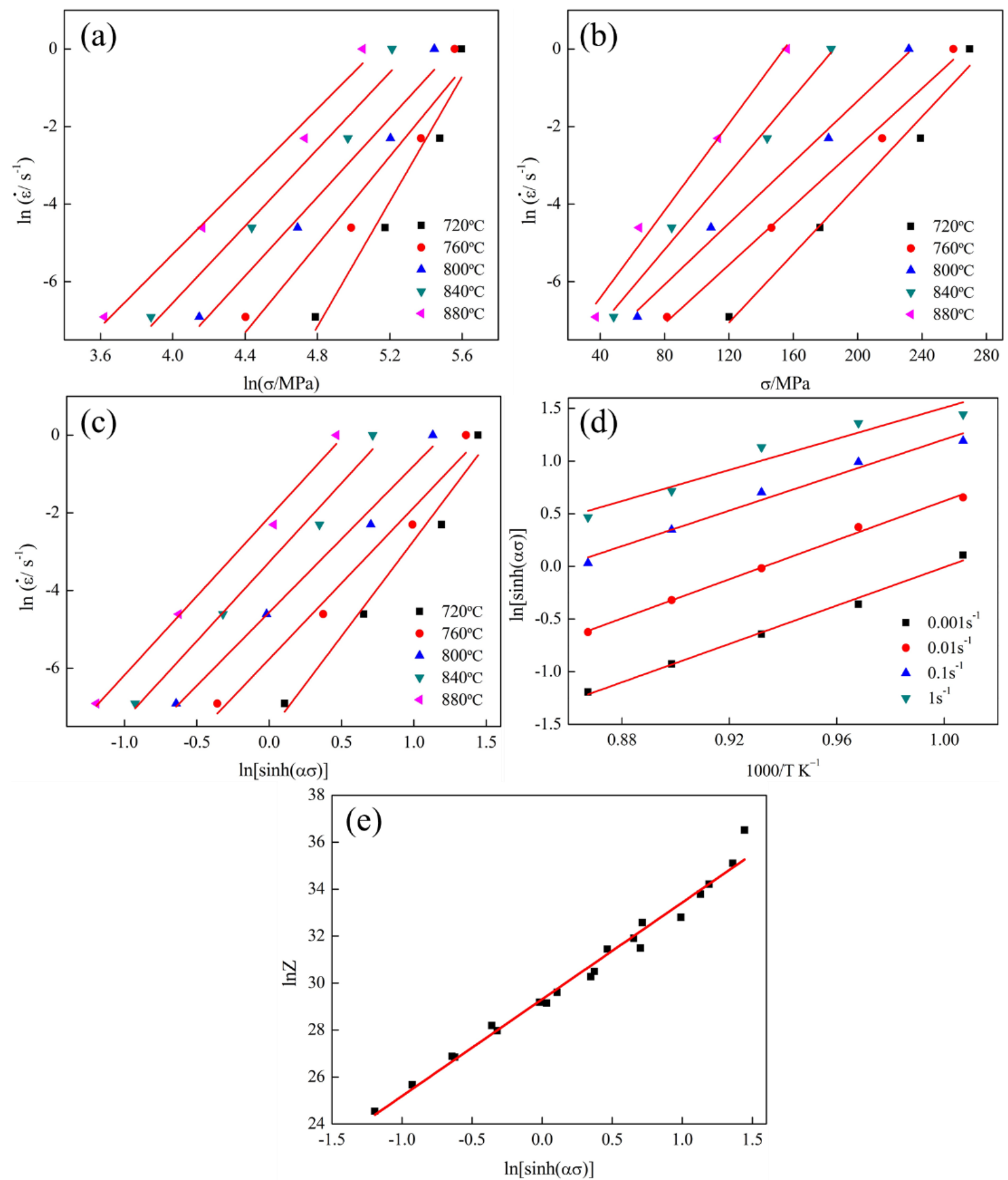

Figure 3. Plots of (a) $\ln \dot{\varepsilon}-\ln \sigma$, (b) $\ln \dot{\varepsilon}-\sigma,(\mathbf{c}) \ln \dot{\varepsilon}-\ln [\sinh (\alpha \sigma)],(\mathbf{d}) \ln [\sinh (\alpha \sigma)]-(1000 / T)$, and (e) $\ln Z-[\sinh (\alpha \sigma)]$.

\subsection{Hot Working Map}

Hot working maps, based on the dynamic materials model, are considered to be an effective method to optimize the hot working parameters and guide the hot deformation process $[19,20]$. According to the DMM, the workpiece could be regarded as an energy dissipater. The total power dissipation $(P)$ consists of two parts: the $G$ part and the $J$ part. 
The $G$ part represents the power dissipation due to plastic deformation, while the $J$ part is relevant to metallurgical microstructure evolution. The mathematical definition of $P$ is [19]

$$
P=\sigma \dot{\varepsilon}=G+J=\int_{0}^{\dot{\varepsilon}} \sigma d \dot{\varepsilon}+\int_{0}^{\sigma} \dot{\varepsilon} d \sigma
$$

The ratio between $G$ and $J$ is called the strain rate sensitivity coefficient, which can be expressed as [21]

$$
m=\frac{d J}{d G}=\frac{\partial(\ln \sigma)}{\partial(\ln \dot{\varepsilon})}
$$

$\dot{\varepsilon}, \sigma$, and $m$ have the following relationship:

$$
\sigma=k \dot{\varepsilon}^{m}
$$

Therefore, $J$ can be written in the form below:

$$
J=\int_{0}^{\sigma} \dot{\varepsilon} d \sigma=\frac{m \sigma \dot{\varepsilon}}{m+1}
$$

When $m=1, J=J_{\max }=\sigma \dot{\varepsilon} / 2$, and the power dissipation efficiency $\eta$ related to $m$ can be expressed as [22]

$$
\eta=\frac{J}{J_{\max }}=\frac{2 m}{m+1}
$$

At a given temperature, the relationship between $\lg \sigma$ and $\lg \dot{\varepsilon}$ can be expressed as

$$
\lg \sigma=a+b \lg \dot{\varepsilon}+\mathrm{c}(\lg \dot{\varepsilon})^{2}+d(\lg \dot{\varepsilon})^{3}
$$

The multinomial coefficients of the cubic polynomial are $a, b, c$, and $d$. Therefore, $m$ can be calculated using the following equation:

$$
m=\frac{d(\lg \sigma)}{d(\lg \dot{\varepsilon})}=b+2 c \lg \dot{\varepsilon}+3 d(\lg \dot{\varepsilon})^{2}
$$

According to the extreme principles of irreversible thermodynamics, flow instabilities could occur if [23]

$$
\xi(\dot{\varepsilon})=\frac{\partial \ln [m /(m+1)]}{\partial \ln \dot{\varepsilon}}+m \leq 0
$$

By substituting Equation (17) into Equation (18), the expression of $\xi(\dot{\varepsilon})$ can be converted to Equation (19):

$$
\xi(\dot{\varepsilon})=\frac{2 c+6 d(\lg \dot{\varepsilon})}{m(m+1) \ln 10}+m
$$

Using the data of the flow stress under different deformation conditions at a true strain from $0.2-0.8$ with an interval of 0.2 , the efficiency of the power dissipation and flow instability are displayed in Figure $4 a, b$, respectively.

According to Figure $4 \mathrm{a}$, the true strain had a significant impact on the value and distribution of $\eta$. The peak values of $\eta$ at a true strain from $0.2-0.8$ are $45.5 \%, 44.1 \%, 42.6 \%$, and $42.3 \%$, respectively, with a tendency to decrease with the true strain. It was found that the valley values appeared at $720^{\circ} \mathrm{C}$ with a stain rate of $1 \mathrm{~s}^{-1}$, indicating that the low temperature and high strain rate were unsuitable for the hot deformation of $\mathrm{Cu}-\mathrm{Ni}-\mathrm{Sn}-\mathrm{Zn}$ $\mathrm{Mn}$. The area where $\eta$ was higher than $40 \%$ diminished gradually as the strain increased. At the true strain of 0.2 , a high $\eta$ over $40 \%$ appeared at three domains: $730-770{ }^{\circ} \mathrm{C}$ with a strain rate of $0.001-0.01 \mathrm{~s}^{-1}, 800-850{ }^{\circ} \mathrm{C}$ with a strain rate of $0.01-0.1 \mathrm{~s}^{-1}$, and $870-880{ }^{\circ} \mathrm{C}$ with a strain rate of $0.01-0.1 \mathrm{~s}^{-1}$. However, at a true strain of 0.8 , the domain with a temperature range of $730-770{ }^{\circ} \mathrm{C}$ and a strain rate range of $0.001-0.01 \mathrm{~s}^{-1}$ owned an $\eta$ 
value higher than $40 \%$, and this domain existed persistently during the whole deformation process. As shown in Figure $4 \mathrm{~b}$, the flow instability regions gathered at a strain rate range from $0.1 \mathrm{~s}^{-1}$ to $1 \mathrm{~s}^{-1}$. Furthermore, there were still several fragmentary flow instability regions distributed in different areas.
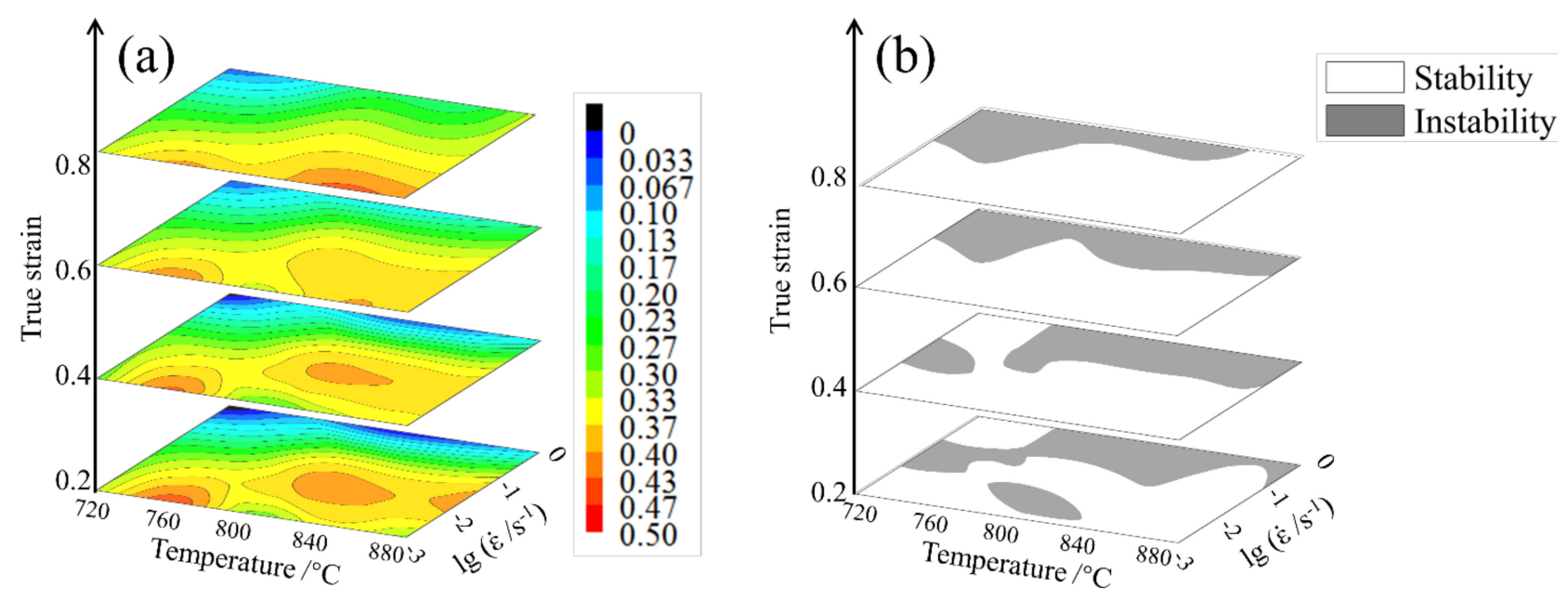

Figure 4. (a) Efficiency of power dissipation and (b) flow instability.

Based on the above analysis, when the samples were deformed at a low strain rate, a high power dissipation efficiency tended to be obtained. While deformed at a high stain rate $\left(0.1-1 \mathrm{~s}^{-1}\right)$, the samples could encounter flow instability.

\subsection{OM Observation of Microstructure Evolution}

Figure 5 shows the $\mathrm{OM}$ images of the alloy deformed at $800{ }^{\circ} \mathrm{C}$ with a strain rate from $0.001 \mathrm{~s}^{-1}$ to $1 \mathrm{~s}^{-1}$. As shown in Figure $5 \mathrm{a}\left(1 \mathrm{~s}^{-1}\right)$ and Figure $5 \mathrm{~b}\left(0.1 \mathrm{~s}^{-1}\right)$, the original equiaxed grains that formed during homogenization were elongated in the direction perpendicular to the compressed direction, leading to a typical compression deformation structure. At a high strain rate of $0.1 \mathrm{~s}^{-1}$ and $1 \mathrm{~s}^{-1}$, few DRX grains appeared in the images, which could be attributed to the short time of the deformation process. However, when the alloy deformed at $800{ }^{\circ} \mathrm{C}$ with a strain rate of 0.01 (Figure $5 \mathrm{c}$ ), fine DRX grains generated along the boundaries of the deformed grains, showing a so-called necklaced structure $[24,25]$. The bulging of the grain boundaries was the typical feature of the nucleation of discontinuous dynamic recrystallization (DDRX). Low-angle subgrains derived from the polygonization of dislocation cells usually form during the process of DRV [26]. The misorientation between the low-angle subgrains around the original grain boundaries increased as the subgrains absorbed the dislocations from the continuous deformation. This promoted the bulging of the grain boundaries and the separation of new DDRX grains [27-29]. When the strain rate continued to decline to $0.001 \mathrm{~s}^{-1}$ (Figure 5d), the amount of DRX grains became larger. This could be attributed to the low strain rate of $0.001 \mathrm{~s}^{-1}$ providing more time for the migration of the subgrain boundaries and the separation of DRX grains. Furthermore, the sizes of the DRX grains increased, compared with those in Figure 5c, due to the coarsening of the DRX grains.

Figure 6 displays the microstructure of the alloy when deformed at a strain rate of $0.01 \mathrm{~s}^{-1}$ under different temperatures. It was noted that the sizes of the elongated grains were related to the temperature of deformation. When the samples compressed at $720^{\circ} \mathrm{C}$ (Figure 6a) and $760{ }^{\circ} \mathrm{C}$ (Figure 6b) with the same strain rate of $0.01 \mathrm{~s}^{-1}$, the sizes of the elongated grains increased gradually. This phenomenon may have been caused by the weak shear effects at the higher temperatures. The DRX grains in the sample deformed at $840{ }^{\circ} \mathrm{C} / 0.01 \mathrm{~s}^{-1}$ (Figure 6c) were those in the sample deformed at $800{ }^{\circ} \mathrm{C} / 0.01 \mathrm{~s}^{-1}$ (Figure $5 c$ ). DRX is a thermally activated process. Once free energy for nucleation supplied 
by a high temperature reaches the critical value, the process of DRX begins. Both the DRX nucleation rate and the nucleus growth rate can be increased by a higher deformation temperature [16]. This could be the reason that the sample deformed at $880{ }^{\circ} \mathrm{C} / 0.01 \mathrm{~s}^{-1}$ (Figure 6d) had serious DRX.
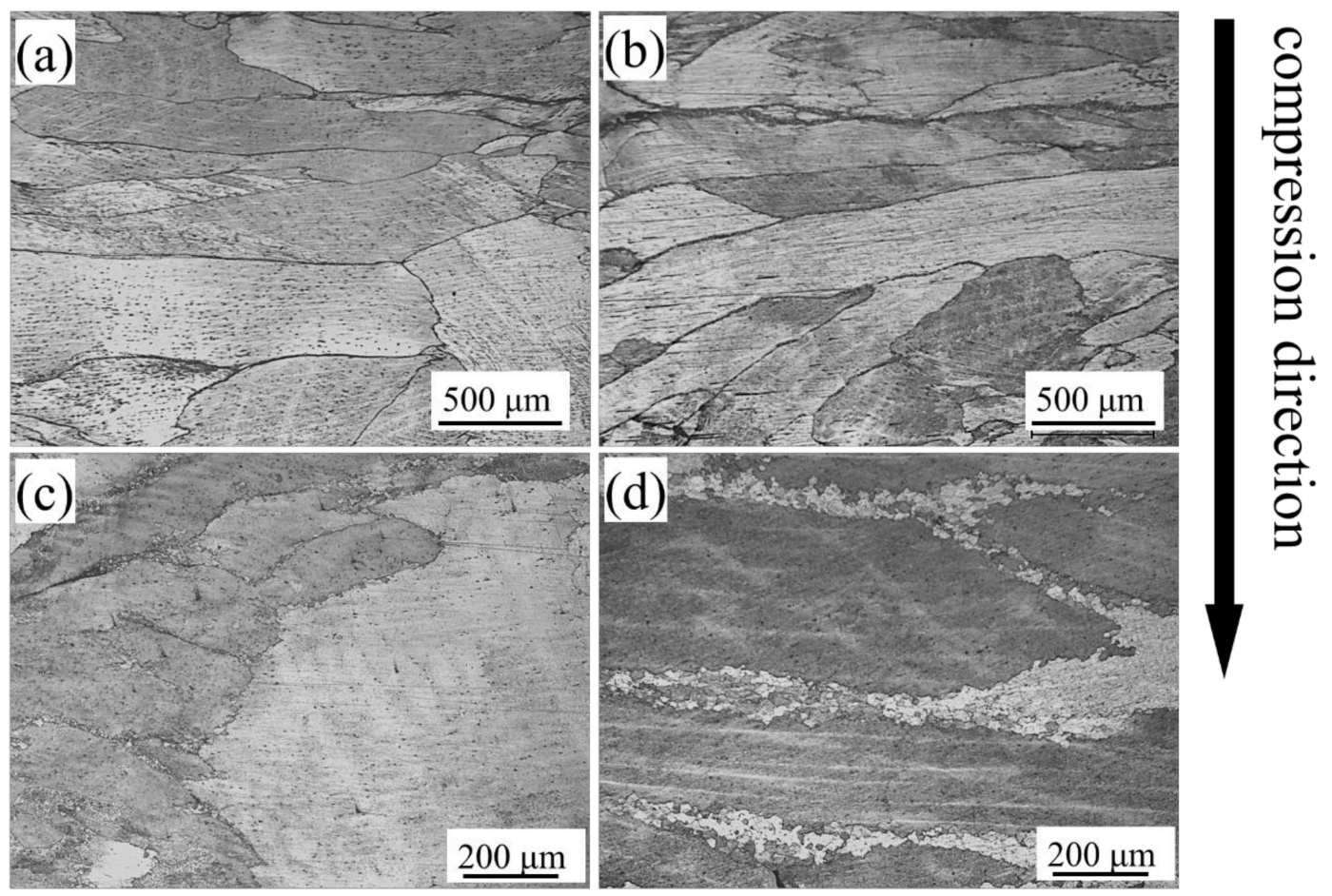

Figure 5. Optical microscopy $(\mathrm{OM})$ images of the alloy deformed at $800{ }^{\circ} \mathrm{C}$ with a strain rate of (a) $1 \mathrm{~s}^{-1},(\mathbf{b}) 0.1 \mathrm{~s}^{-1}$, (c) $0.01 \mathrm{~s}^{-1}$, and (d) $0.001 \mathrm{~s}^{-1}$.
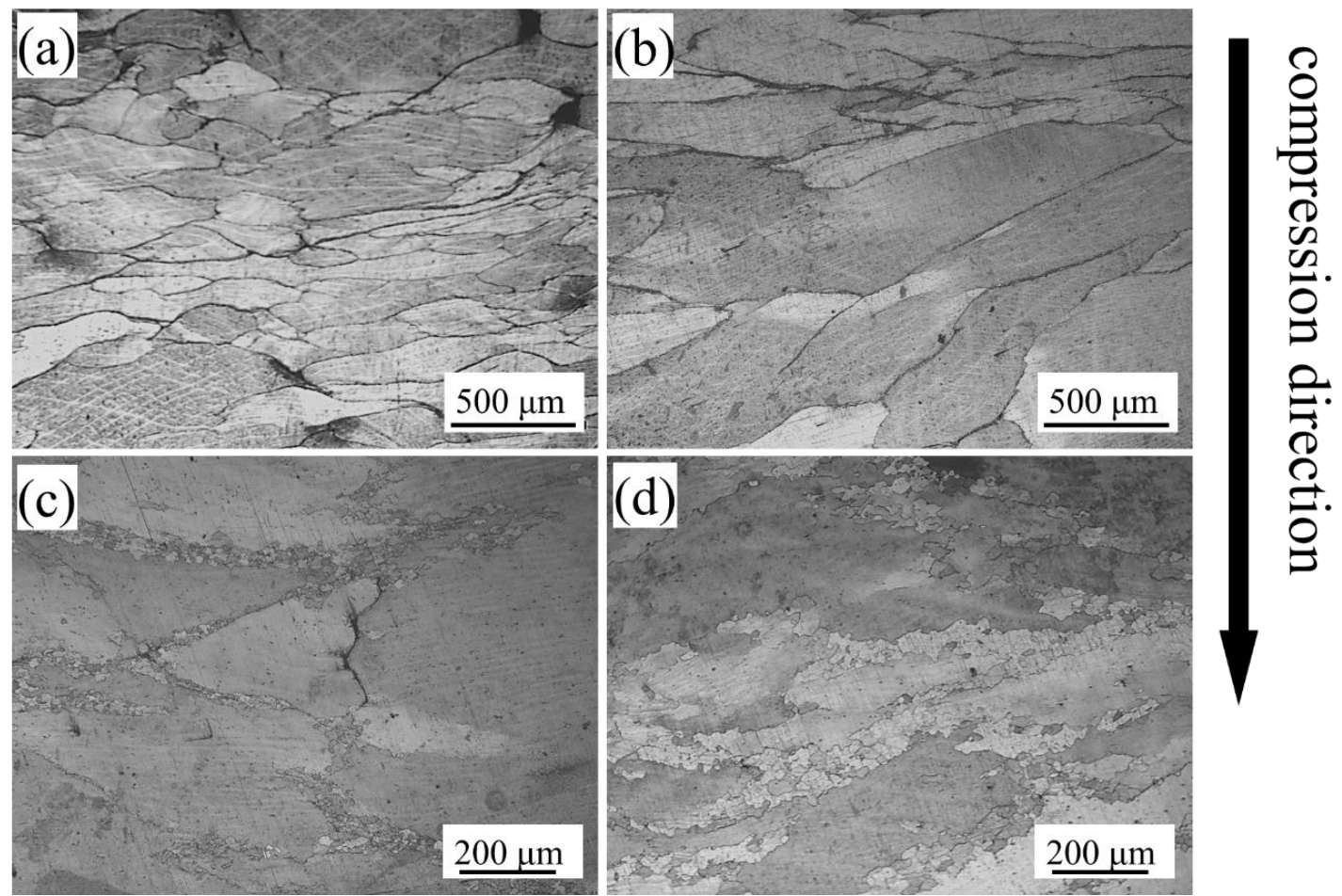

Figure 6. OM images of the alloy deformed at a strain rate of $0.01 \mathrm{~s}^{-1}$ under temperatures of (a) $720^{\circ} \mathrm{C},(\mathbf{b}) 760{ }^{\circ} \mathrm{C},(\mathbf{c}) 840{ }^{\circ} \mathrm{C}$, and (d) $880{ }^{\circ} \mathrm{C}$. 
In general, the temperature and strain rate affected the DRX behavior a lot during the hot deformation process. A high temperature and low strain rate can benefit the nucleation of DRX because they provide the necessary energy or time conditions.

\subsection{TEM Observation of Microstructure Evolution}

Figure 7 shows the TEM images of the samples deformed at different conditions. When the sample was deformed at $720{ }^{\circ} \mathrm{C}$ with a strain rate of $0.001 \mathrm{~s}^{-1}$, as shown in Figure $7 \mathrm{a}$, a large number of dislocations appeared and tangled with each other. The dislocation network generated, which is marked by an arrow in the image. A series of parallel shear deformation bands indicate that a shear deformation occurred in the grain. As the strain rate increased to $1 \mathrm{~s}^{-1}$ at $720^{\circ} \mathrm{C}$ (Figure $7 \mathrm{~b}$ ), subgrains formed because of the DRV process. When the sample was deformed at a low temperature and high strain rate, dislocations accumulated rapidly up to the critical value. Then, movement of the dislocations, including cross-slip of the screw dislocation and climbing of the edge dislocation, occurred, leading to the formation of dislocation cells. The subgrains could further keep their shape after the polygonization of the dislocation cell boundaries. DRV was the dominant softening effect at a low temperature and high strain rate. Figure $7 \mathrm{c}$ displays the formation of DRX grains with a low density of dislocation inside the grains when the deformation was conducted at $800{ }^{\circ} \mathrm{C}$ and $0.001 \mathrm{~s}^{-1}$. The low-angle boundaries of the subgrains would convert to high-angle boundaries after absorbing the dislocations, followed by generation of the DRX grains. Compared with Figure 7c, the density of the dislocations in the newly formed DRX grains was higher in Figure $7 \mathrm{~d}$ when the sample was deformed with a high stain rate of $0.1 \mathrm{~s}^{-1}$ at $800{ }^{\circ} \mathrm{C}$. As the deformation temperature increased to $880{ }^{\circ} \mathrm{C}$ with a strain rate of $1 \mathrm{~s}^{-1}$, there were few dislocations remaining in the DRX grains with smooth and straight boundaries, as shown in Figure 7e.

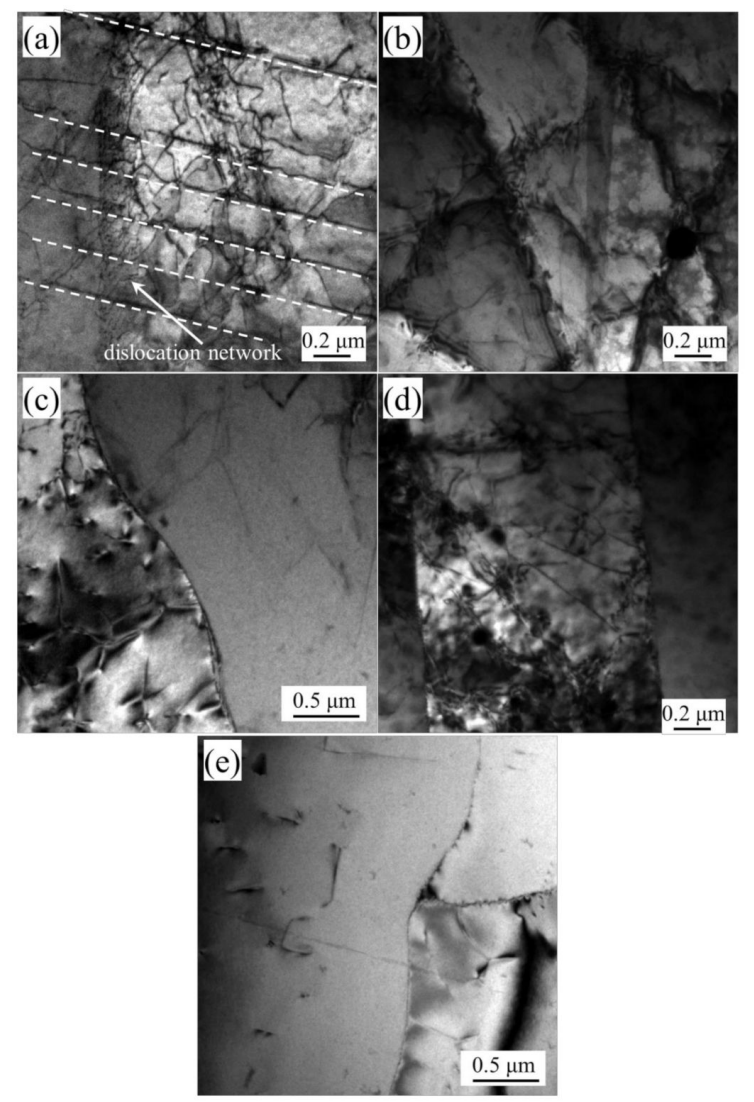

Figure 7. Transmission electron microscopy (TEM) images of the microstructures of samples deformed at different conditions: (a) $720^{\circ} \mathrm{C}$ and $0.001 \mathrm{~s}^{-1}$, (b) $720^{\circ} \mathrm{C}$ and $1 \mathrm{~s}^{-1}$, (c) $800^{\circ} \mathrm{C}$ and $0.001 \mathrm{~s}^{-1}$, (d) $800{ }^{\circ} \mathrm{C}$ and $0.1 \mathrm{~s}^{-1}$, and (e) $880^{\circ} \mathrm{C}$ and $1 \mathrm{~s}^{-1}$. 


\section{Discussion}

\subsection{Relationship between the Hot Working Map and the Microstructure}

To verify the accuracy of the hot processing maps constructed in this work, a hot working map of deformed $\mathrm{Cu}-\mathrm{Ni}-\mathrm{Sn}-\mathrm{Zn}-\mathrm{Mn}$ alloys with a true strain of 0.9 was taken as an example in Figure 8. Pictures of the microstructures of several conditions for discussion are also displayed in Figure 8. When the alloy deformed at a low temperature and high strain rate, the power dissipation efficiency $\eta$ was quite low, being only about $3.7 \%$ at a temperature of $720^{\circ} \mathrm{C}$ with a strain rate of $1 \mathrm{~s}^{-1}$, as shown in Figure 8a. At the domain of the temperature range from $720{ }^{\circ} \mathrm{C}$ to $800{ }^{\circ} \mathrm{C}$ and a strain rate range from $0.1 \mathrm{~s}^{-1}$ to $1 \mathrm{~s}^{-1}$, the values of $\eta$ were all below $23 \%$. This was because the low temperature and high strain rate could not provide sufficient energy or time for dynamic recrystallization, which is bad for the hot deformation process. At the same time, an instability area marked by a gray shade appeared in this domain. Flow instabilities are usually associated with shear bands, cracks, and flow localization $[15,30,31]$. When the alloy is deformed at a high strain rate, adiabatic deformation heat generates because of the difficulty of heat conduction, leading to the flow localization [16]. While the alloy is deformed at a low temperature, retards the motion of dislocation is retarded, leading to the appearance of micro-cracks. Another two instability areas arose at a low-temperature area $\left(720-740{ }^{\circ} \mathrm{C}\right.$ and $\left.0.001-0.01 \mathrm{~s}^{-1}\right)$ and a high-strain rate area $\left(810-860^{\circ} \mathrm{C}\right.$ and $\left.0.1-1 \mathrm{~s}^{-1}\right)$. Considering the two factors of $\eta$ and the flow instability, the conditions of a low temperature and a high strain rate were not suitable for the hot deformation of this alloy. Figure $8 \mathrm{~b}-\mathrm{f}$ shows the images of the microstructure of the alloy deformed under the flow instability domain conditions. Flow localization and defects of deformation, such as cracks and cavities at the junctions of the grain boundaries, were found. These figures ulteriorly demonstrate the inadaptability of a low temperature and high strain rate. A high value of $\eta$ tended to appear when the strain rate was low. The peak value of $\eta$ in the working map was $41 \%$ when the temperature was $760-780{ }^{\circ} \mathrm{C}$ with strain rate of $0.001 \mathrm{~s}^{-1}$ and $820-880^{\circ} \mathrm{C}$ with a strain rate of $0.001 \mathrm{~s}^{-1}$. The OM images of the microstructures of the samples deformed with temperatures of $760{ }^{\circ} \mathrm{C}, 840{ }^{\circ} \mathrm{C}$, and $880{ }^{\circ} \mathrm{C}$ at a strain rate of $0.001 \mathrm{~s}^{-1}$ are shown is Figure $8 \mathrm{~g}-\mathrm{i}$, respectively. The DRX structures were obvious at a low strain rate, indicating that a high $\eta$ was closely associated with the DRX structures. With the increasing temperature, the DRX grains grew bigger, and the size distribution was more uniform.

Based on the instability and value of $\eta$, the hot working map was divided into three parts. Domain A represents an unsuitable deformation area for the appearance of deformation defects, which should be avoided in the deformation process. Domain B represents a safe deformation area with a high $\eta$ value. Deformation in this area is helpful to obtain uniformly distributed dynamic recrystallization (DRX) structures that generally own good mechanical properties. The optimal hot deformation parameters for $\mathrm{Cu}-\mathrm{Ni}-\mathrm{Sn}-\mathrm{Zn}-\mathrm{Mn}$ should be selected from this domain, which were determined to be a temperature range of $820-860^{\circ} \mathrm{C}$ and a strain rate range of $0.001-0.01 \mathrm{~s}^{-1}$. The reason for this choice was that the alloy possessed fine and homogeneous DRX structures. The area between Domain A and Domain B is Domain C, representing an unsafe area. In this area, the value of $\eta$ is not high, and it is located next to an unsuitable deformation area, leading to indeterminacy of the deformation process. It is better to keep away from this area. 

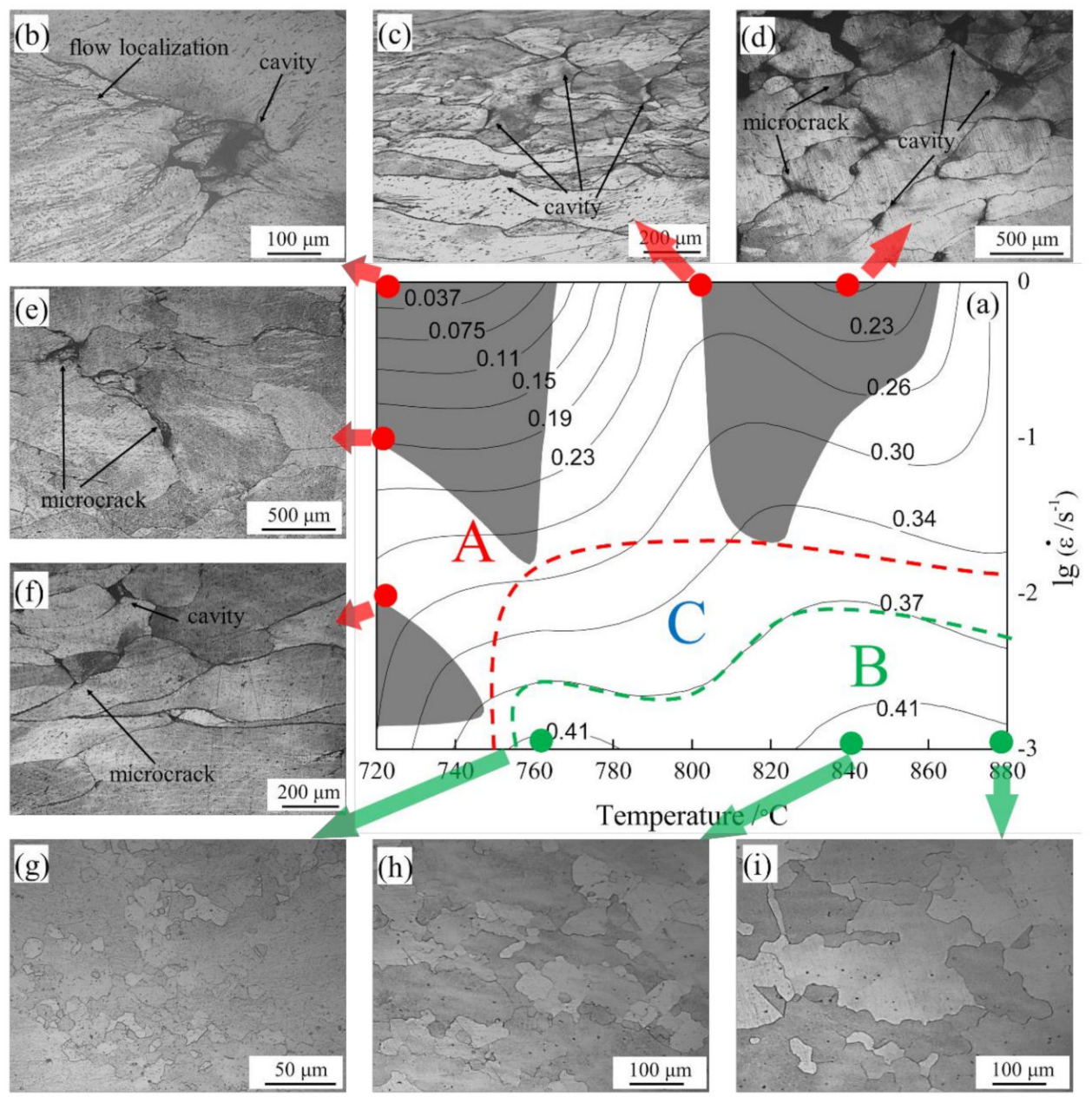

Figure 8. Hot working map of the samples deformed at a true strain of 0.9 and the corresponding representative microstructure. (a) hot working map; (b) $720^{\circ} \mathrm{C}$ and $1 \mathrm{~s}^{-1}$, (c) $800{ }^{\circ} \mathrm{C}$ and $1 \mathrm{~s}^{-1}$, (d) $840{ }^{\circ} \mathrm{C}$ and $1 \mathrm{~s}^{-1}$, (e) $720{ }^{\circ} \mathrm{C}$ and $0.1 \mathrm{~s}^{-1}$, (f) $720{ }^{\circ} \mathrm{C}$ and $0.01 \mathrm{~s}^{-1},(\mathrm{~g}) 760{ }^{\circ} \mathrm{C}$ and $0.001 \mathrm{~s}^{-1}$, (h) $840{ }^{\circ} \mathrm{C}$ and $0.001 \mathrm{~s}^{-1}$, (i) $880{ }^{\circ} \mathrm{C}$ and $0.001 \mathrm{~s}^{-1}$.

\subsection{Change Rules of Power Dissipation Efficiency}

The results show that the power dissipation efficiency $\eta$ was affected significantly by the deformation temperature, strain rate, and true strain. The value of $\eta$ could reflect the deformation characteristics. Generally, a low $\eta$ meant that it was hard for the material to consume the heat produced from deformation during microstructure transformation. As such, flow localization may take place. A high $\eta$ often related to a uniform DRX structure with good workability, which is desired for deformation [32-34]. On the other hand, the softening mechanism can be evaluated according to the value of $\eta$. When $\eta$ was below $30 \%$, DRV was the main softening mechanism. When $\eta$ was over $90 \%$, superplasticity was the main softening mechanism. DRX played a dominant role while the value of $\eta$ was between $30 \%$ and $60 \%$ [16]. Therefore, it is necessary to figure out the change rules of the power dissipation efficiency $\eta$ with various deformation temperatures, strain rates, and true strains.

In Figure 9, each small picture represents a deformation process under the specified hot deformation condition. In each small picture, the curve represents the variation of $\eta$ with the increase of the true strain. The peak values $\left(\eta_{p}\right)$ and valley values $\left(\eta_{v}\right)$ of $\eta$ are displayed in every separate picture. The value of $\eta_{p}$ increased with the increase of the deformation temperature and decrease of the strain rate, suggesting that the softening mechanism changed from DRV to DRX. The $\eta_{v}$ value had a similar rule under most of the deformation conditions. The results with values of $\eta_{p}$ below $30 \%$ are included in the dotted box. The softening mechanism of the samples deformed in this area was always 
DRV during the whole deformation process. It is worth noting that this area was integrally located in Domain A in Figure 8, where flow instability may have taken place and hot deformation was not appropriate to conduct.

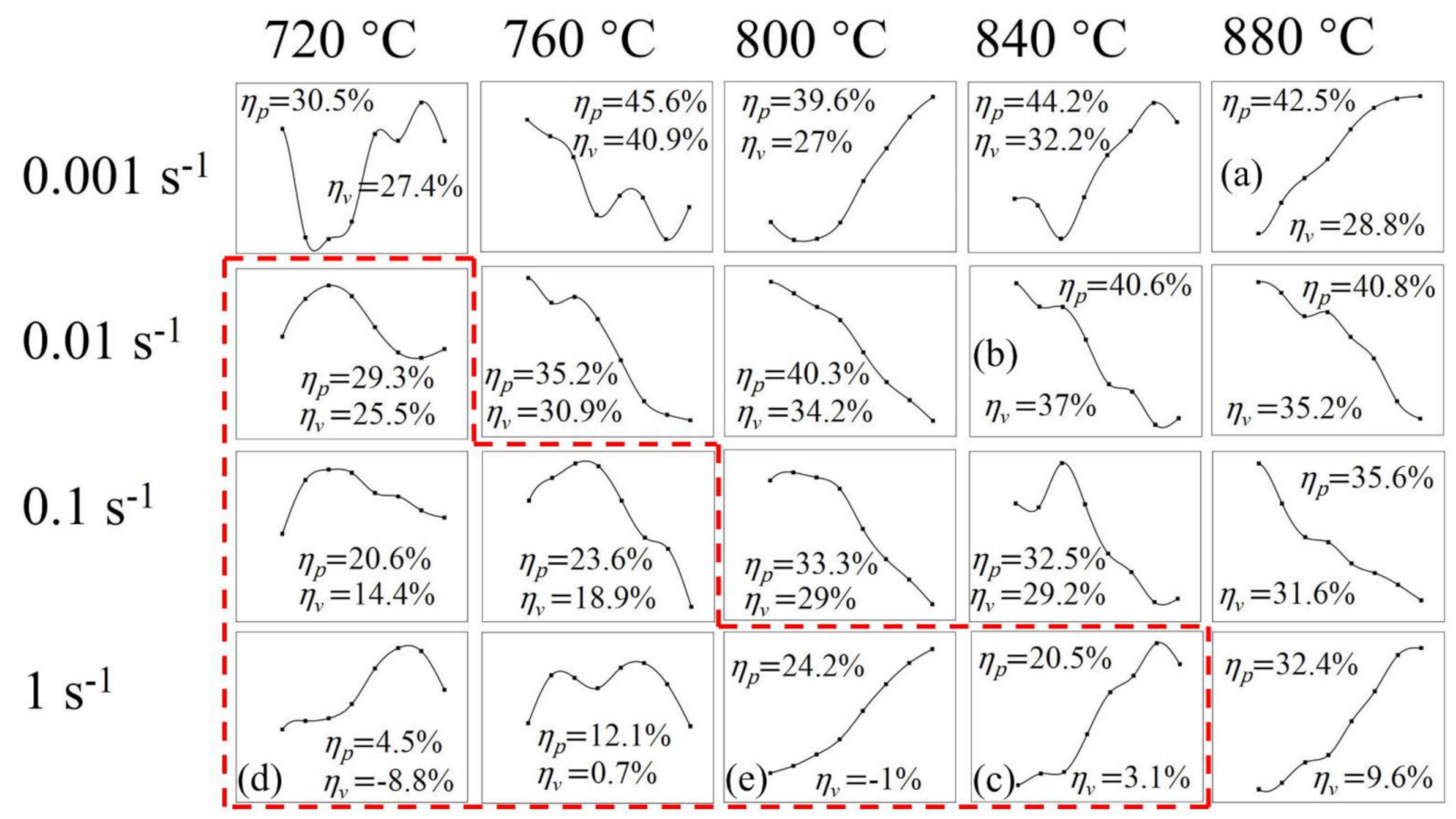

Figure 9. Change rules of $\eta$ with the true strain under different deformation conditions.

At each small picture shown in Figure 9, the change rule of $\eta$ can be mainly divided into four kinds: increase first and then decrease; decrease first and then increase; increase continuously; and decrease continuously. The value of $\eta$ increased from $28.8 \%$ to $42.5 \%$, as shown in Figure 9a. Under this condition, DRV was the main softening mechanism at first. When the energy stored in the material increased to a critical value, DRX began to happen and dominated gradually. As such, $\eta$ rose to become higher than $30 \%$. In Figure $9 b$, the minimum value of $\eta$ was 37\%, indicating DRX was the prime softening mechanism during the whole process. However, the power used for DRX continued to reduce at later period, so $\eta$ decreased from $40.6 \%$ continuously to $37 \%$. According to Equation (15), $m$ had the same change rule as $\eta$. When $\eta$ decreased, $m$ decreased at the same time. Therefore, $G$ part increased. The value of $\eta$ in Figure $9 c$ increased from 3.1\% to 20.5\%, and DRV was the dominant mechanism under this condition. The continuous rise of $\eta$ shows that the DRV behavior took place in more and more places in the samples during the deformation process. In Figure $9 \mathrm{~d}, \mathrm{e}, \eta_{v}$ was found to be negative, with values of $-8.8 \%$ and $-1 \%$, respectively, indicating a negative value of $m$. The same phenomenon was found in the study by Chaudhuri et al. [35], who thought that the phenomenon implied flow localization or an unstable flow at a high strain rate.

It can be concluded from the analysis above that deformation conditions can significantly affect the value of the power dissipation efficiency $\eta$, and the deformation behavior can be speculated according to the change rule of $\eta$.

\section{Conclusions}

1. The flow stress curves of the $\mathrm{Cu}-\mathrm{Ni}-\mathrm{Sn}-\mathrm{Zn}-\mathrm{Mn}$ alloy can be divided into three parts: a work hardening stage, a softening stage, and a steady stage. However, at a low temperature $\left(720{ }^{\circ} \mathrm{C}\right)$ and high strain rate $\left(0.1 \mathrm{~s}^{-1}\right.$ and $\left.1 \mathrm{~s}^{-1}\right)$, the steady stage is not evident; 
2. With the increase of the true strain from 0.2 to 0.8 , the domain of $730-770{ }^{\circ} \mathrm{C}$ and $0.001-0.01 \mathrm{~s}^{-1}$ invariably owned a power dissipation efficiency over $40 \%$, and flow instability mainly existed at a strain rate from $0.1 \mathrm{~s}^{-1}$ to $1 \mathrm{~s}^{-1}$. When the true strain was 0.9 , the appropriate deformation conditions were $820-860^{\circ} \mathrm{C}$ with a strain rate of $0.001-0.01 \mathrm{~s}^{-1}$ for the alloy;

3. The appearance of bulging of the grain boundaries indicates that discontinuous dynamic recrystallization was the prime DRX nucleation mechanism. A high temperature and a low strain rate can promote the nucleation of DRX;

4. The area with a peak value of a power dissipation efficiency over $30 \%$ during the whole deformation process was located at the domains of high temperatures and low strain rates. When the power dissipation efficiency was over 30\%, DRX became the main softening mechanism.

Author Contributions: Conceptualization, Y.J. and Z.X.; formal analysis, Y.J., X.W. and X.Z.; investigation, Y.J. and Z.L.; project administration, H.J. and G.C.; resources, Z.X. and X.Z.; supervision, Z.X. and X.S.; validation, Y.J. and H.J.; writing—original draft, Y.J. and X.W.; writing—review and editing, Y.J. and Z.X. All authors have read and agreed to the published version of the manuscript.

Funding: This research was funded by the National Key Research and Development Program of China (2017YFB0306100), National Natural Science Foundation of China (51974375), Key Research and Development Program of Shandong Province, China (2019JZZY010362), and the Project of State Key Laboratory of Powder Metallurgy at Central South University, Changsha, China.

Institutional Review Board Statement: Not applicable.

Informed Consent Statement: Not applicable.

Data Availability Statement: No new data were created or analyzed in this study. Data sharing is not applicable to this article.

Acknowledgments: In this section, you can acknowledge any support given which is not covered by the author contribution or funding sections. This may include administrative and technical support, or donations in kind (e.g., materials used for experiments).

Conflicts of Interest: The authors declare no conflict of interest.

\section{References}

1. Si, L.; Zhou, L.; Zhu, X.; Sanhua, L.; Leinuo, S.; Qiyi, D. Microstructure and property of $\mathrm{Cu}-2.7 \mathrm{Ti}-0.15 \mathrm{Mg}-0.1 \mathrm{Ce}-0.1 \mathrm{Zr}$ alloy treated with a combined aging process. Mater. Sci. Eng. A 2016, 650, 345-353. [CrossRef]

2. Li, C.; Wang, X.; Li, B.; Shi, J.; Liu, Y.; Xiao, P. Effect of cold rolling and aging treatment on the microstructure and properties of Cu-3Ti-2Mg alloy. J. Alloys Compd. 2020, 818, 152915. [CrossRef]

3. Lei, Q.; Li, Z.; Zhu, A.; Qiu, W.; Liang, S. The transformation behavior of $\mathrm{Cu}-8.0 \mathrm{Ni}-1.8 \mathrm{Si}-0.6 \mathrm{Sn}-0.15 \mathrm{Mg}$ alloy during isothermal heat treatment. Mater. Charact. 2011, 62, 904-911. [CrossRef]

4. Jiang, Y.; Li, Z.; Xiao, Z.; Xing, Y.; Zhang, Y.; Fang, M. Microstructure and Properties of a Cu-Ni-Sn Alloy Treated by Two-Stage Thermomechanical Processing. JOM 2019, 71, 2734-2741. [CrossRef]

5. Yu, Q.X.; Li, X.N.; Wei, K.R.; Li, Z.M.; Zheng, Y.H.; Li, N.J.; Cheng, X.T.; Wang, C.Y.; Wang, Q.; Dong, C. Cu-Ni-Sn-Si alloys designed by cluster-plus-glue-atom model. Mater. Design 2019, 167, 107641. [CrossRef]

6. Zhang, Y.; Xiao, Z.; Zhao, Y.; Li, Z.; Xing, Y.; Zhou, K. Effect of thermo-mechanical treatments on corrosion behavior of Cu-15Ni-8Sn alloy in $3.5 \mathrm{wt} \% \mathrm{NaCl}$ solution. Mater. Chem. Phys. 2017, 199, 54-66. [CrossRef]

7. Luo, B.; Li, D.; Zhao, C.; Wang, Z.; Luo, Z; Zhang, W. A low Sn content Cu-Ni-Sn alloy with high strength and good ductility. Mater. Sci. Eng. A 2019, 746, 154-161. [CrossRef]

8. Ouyang, Y.; Gan, X.; Li, Z.; Zhou, K.; Zhang, S.; Jiang, Y.; Zhang, X. Microstructure evolution of a Cu-15Ni-8Sn-0.8Nb alloy during prior deformation and aging treatment. Mater. Sci. Eng. A 2017, 704, 128-137. [CrossRef]

9. Kim, Y.-K.; Park, S.-H.; Lee, K.-A. Effect of post-heat treatment on the thermophysical and compressive mechanical properties of Cu-Ni-Sn alloy manufactured by selective laser melting. Mater. Charact. 2020, 162, 110194. [CrossRef]

10. Zhu, J.; Ma, L.; Dwyer-Joyce, R.S. Friction and wear of Cu-15 wt\%Ni-8 wt\%Sn bronze lubricated by grease at room and elevated temperature. Wear 2020, 460, 203474. [CrossRef]

11. Guo, Z.; Jie, J.; Liu, S.; Liu, J.; Yue, S.; Zhang, Y.; Li, T. Solidification Characteristics and Segregation Behavior of Cu-15Ni-8Sn Alloy. Met. Mater. Trans. A 2020, 51, 1229-1241. [CrossRef] 
12. Zhang, L.; Li, Z.; Lei, Q.; Qiu, W.T.; Luo, H.T. Hot deformation behavior of Cu-8.0Ni-1.8Si-0.15Mg alloy. Mater. Sci. Eng. A 2011, 528, 1641-1647. [CrossRef]

13. Sun, H.; Zhang, Y.; Volinsky, A.A.; Wang, B.; Tian, B.; Song, K.; Chai, Z.; Liu, Y. Effects of Ag Addition on Hot Deformation Behavior of Cu-Ni-Si Alloys. Adv. Eng. Mater. 2017, 19, 1600607. [CrossRef]

14. Wang, B.; Zhang, Y.; Tian, B.; Yakubov, V.; An, J.; Volinsky, A.A.; Liu, Y.; Song, K.; Li, L.; Fu, M. Effects of Ce and Y addition on microstructure evolution and precipitation of $\mathrm{Cu}-\mathrm{Mg}$ alloy hot deformation. J. Alloys Compd. 2019, 781, 118-130. [CrossRef]

15. Liu, J.; Wang, X.; Liu, J.; Liu, Y.; Li, H.; Wang, C. Hot deformation and dynamic recrystallization behavior of Cu-3Ti-3Ni-0.5Si alloy. J. Alloys Compd. 2019, 782, 224-234. [CrossRef]

16. Li, C.; Huang, L.; Zhao, M.; Zhang, X.; Li, J.; Li, P. Influence of hot deformation on dynamic recrystallization behavior of 300M steel: Rules and modeling. Mater. Sci. Eng. A 2020, 797, 139925. [CrossRef]

17. Jonas, J.J.; Sellars, C.M.; Tegart, W.J.M. Strength and structure under hot-working conditions. Met. Rev. 1969, 14, 1-24. [CrossRef]

18. Zener, C.; Hollomon, J.H. Effect of Strain Rate upon Plastic Flow of Steel. J. Appl. Phys. 1944, 15, 22-32. [CrossRef]

19. Prasad, Y.V.R.K.; Gegel, S.M.D.; Malas, J.C.; Morgan, J.T.; Lark, K.A.; Barker, D.R. Modeling of Dynamic Material Behavior in Hot Deformation: Forging of Ti-6242. Met. Trans. A 1984, 15, 1883-1892. [CrossRef]

20. Prasad, Y.V.R.K.; Seshacharyulu, T. Modelling of hot deformation for microstructural control. Int. Mater. Rev. 2013, 43, 243-258. [CrossRef]

21. Prasad, Y.V.R.K.; Rao, K.P. Processing maps and rate controlling mechanisms of hot deformation of electrolytic tough pitch copper in the temperature range $300-950^{\circ}$ C. Mater. Sci. Eng. A 2005, 391, 141-150. [CrossRef]

22. Prasad, Y.V.R.K. Processing maps: A status report. J. Mater. Eng. Perform. 2003, 12, 638-645. [CrossRef]

23. Prasad, Y.V.R.K.; Seshacharyulu, T. Processing maps for hot working of titanium alloys. Mater. Sci. Eng. A 1998, 243, 82-88. [CrossRef]

24. Liao, Q.; Jiang, Y.; Le, Q.; Chen, X.; Cheng, C.; Hu, K.; Li, D. Hot deformation behavior and processing map development of AZ110 alloy with and without addition of La-rich Mish Metal. J. Mater. Sci. Technol. 2021, 61, 1-15. [CrossRef]

25. Liu, P.; Zhang, R.; Yuan, Y.; Cui, C.; Zhou, Y.; Sun, X. Hot deformation behavior and workability of a Ni-Co based superalloy. J. Alloys Compd. 2020, 831, 154618. [CrossRef]

26. Ke, B.; Ye, L.; Tang, J.; Zhang, Y.; Liu, S.; Lin, H.; Dong, Y.; Liu, X. Hot deformation behavior and 3D processing maps of AA7020 aluminum alloy. J. Alloys Compd. 2020, 845, 156113. [CrossRef]

27. Gourdet, S.; Montheillet, F. An experimental study of the recrystallization mechanism during hot deformation of aluminium. Mater. Sci. Eng. A 2000, 283, 274-288. [CrossRef]

28. McQueen, H.J.; Imbert, C.A.C. Dynamic recrystallization: Plasticity enhancing structural development. J. Alloys Compd. 2004, 378, 35-43. [CrossRef]

29. Huang, W.; Yang, X.; Yang, Y.; Mukai, T.; Sakai, T. Effect of yttrium addition on the hot deformation behaviors and microstructure development of magnesium alloy. J. Alloys Compd. 2019, 786, 118-125. [CrossRef]

30. Zhang, Y.; Liu, P.; Tian, B.; Liu, Y.; Li, R.; Xu, Q. Hot deformation behavior and processing map of Cu-Ni-Si-P alloy. Trans. Nonferr. Met. Soc. China 2013, 23, 2341-2347. [CrossRef]

31. Wang, B.; Zhang, Y.; Tian, B.; An, J.; Volinsky, A.A.; Sun, H.; Liu, Y.; Song, K. Effects of Ce addition on the Cu-Mg-Fe alloy hot deformation behavior. Vacuum 2018, 155, 594-603. [CrossRef]

32. Wang, J.; Zhao, G.; Li, M. Establishment of processing map and analysis of microstructure on multi-crystalline tungsten plastic deformation process at elevated temperature. Mater. Design 2016, 103, 268-277. [CrossRef]

33. Wang, K.; Lu, S.; Fu, M.W.; Li, X.; Dong, X. Optimization of $\beta /$ near- $\beta$ forging process parameters of Ti-6.5Al-3.5Mo-1.5Zr-0.3Si by using processing maps. Mater. Charact. 2009, 60, 492-498. [CrossRef]

34. Quan, G.-Z.; Zhao, L.; Chen, T.; Wang, Y.; Mao, Y.-P.; Lv, W.-Q.; Zhou, J. Identification for the optimal working parameters of as-extruded $42 \mathrm{CrMo}$ high-strength steel from a large range of strain, strain rate and temperature. Mater. Sci. Eng. A 2012, 538, 364-373. [CrossRef]

35. Chaudhuri, A.; Behera, A.N.; Sarkar, A.; Kapoor, R.; Ray, R.K.; Suwas, S. Hot deformation behaviour of Mo-TZM and understanding the restoration processes involved. Acta Mater. 2019, 164, 153-164. [CrossRef] 